\title{
Use of Sensitivity Analysis a Decision Support System in Automotive Painting Technology Investment
}

\author{
Hamizan Osman*, Adi Saptari and Ahmad Yusuf Ismail \\ Department of Manufacturing Management, Faculty of Manufacturing Engineering Universiti \\ Teknikal Malaysia, Melaka, Malaysia; \\ hamizan@proton.com, adi@utem.edu.my, ahmadyusuf.ismail@utem.edu.my
}

\begin{abstract}
Background/Objective: This paper presents a study on the use of Sensitivity Analysis (SA) approach to support a decision-making in capital investment and secondary tools Value Added and Value Engineering (VA/VE) to optimize the capital investment in automotive painting technology. Methods/Analysis: First, the investment requirement in new painting technology is identified. Using the in-house company limitation and regulation, the requirement is then simplified in order to ease the further process in investment calculation. The sensitivity analysis is then being used to analyze the financial investment calculation to help the company's top management making decision. The VA/VE then will be used to reduce further the equipment and building cost. Findings: The value engineering methodology carried out by Small Group Activities (SGA) reduced the cost while maintaining the same intended output. From the calculation result, it is found that the sensitivity analysis is effectively support and help the decision making process considerably. Applications/ Improvements: Sensitivity analysis provides several alternatives to the company to consider financial investment options.
\end{abstract}

Keywords: Automotive Painting, Decision Support, Level of Technology, Localization, Sensitivity Analysis, Value Analysis

\section{Introduction}

National Automotive Policy stated by year 2020, the automotive industry will provide 550,000 employment opportunities with involvement of 430 local vendors. In NAP 2014는 government has given special emphasis on export of local production cars and increase localization of automotive component. With the annual export target of 250,000 units, the quality of painting job in the manufacturing process must be at global standard and able to withstand the extended warranty of minimum 5 years. Today, the car-manufacturing trend focuses on the production of the energy-efficient vehicles, which initiates many car manufacturers to start producing vehicles using aluminum, magnesium and super high tensile materials in order to reduce car weight. Thus, to uphold this latest requirement, the painting shop needs to be upgraded to meet this advanced technical specification requirement. Unfortunately, Malaysians companies do not have the paint shop to carry out this requirement. Even far, reach to give five years warranty on harsh usage condition. It is crucial that all car manufacturers put effort in ensuring the quality of their car paint meets acceptable standard required by Global OEM standard. For instance, German

${ }^{*}$ Author for correspondence 
carmakers have raised car body material standard and paint quality specification which local companies in Malaysia are not able to undertake. Mercedes Benz confirmed that the aluminum body of its cars requires special processes that force the company to desire auto motive painting process from overseas. The process of automotive painting is important to provide corrosion protection, mechanical protection, such as scratch, atmospheric and weather protection, and aesthetical appearance ${ }^{2}$. Due to this extreme standard, European car assemblers i.e. BMW, Mercedes Benz, Citroen and Peugeot in Malaysia have imported painted body shells from their origin plant in Europe According to Howard and Miemczyk ${ }^{3}$, the biggest bottleneck in automotive production is in the paint shop process. As such, the selections of process and technology level are crucial to determine the level of quality, environment, and safety to workforce. All these aspects will directly give an impact to initial capital investment of the company. Companies in Malaysia need to determine the amount of investment to be put forth in enabling them to opt for the acceptable level of technology according to their business needs. Thus, Sensitivity Analysis (SA) will act as the important tool that is to be used to stimulate the financial ratio for the company and shareholders to make a complex decision. This work proves that SA is the financial tool to support management decision on capital investment and the secondary tools VA/VE to optimize the investment.

\section{Methods}

\subsection{Research Procedures}

To achieve this objective, identification of new paint technology (challenger technology) was performed. This was done through establishing Small Group Activities (SGA) such as inviting senior engineers in the plant and the experts in automotive painting technology. The second step is to conduct financial feasibility study. In this step, all information to perform feasibility study has been collected. These include, among others, the market and volume of cars, all cost involved, method of depreciation,

Table 1. Summary of research framework

\begin{tabular}{|c|c|}
\hline Objectives & Concept / Theory/ Model \\
\hline $\begin{array}{l}\text { 1. To examine the alternative } \\
\text { technology and investment in } \\
\text { establishing the Paint Shop. }\end{array}$ & $\begin{array}{l}\text { External and Internal Analysis by SGA. } \\
\text { 1. Technology identification } \\
\text { 2. Technology level } \\
\text { 3. Investment requirement }\end{array}$ \\
\hline $\begin{array}{l}\text { 2. To conduct financial feasibility study } \\
\text { and to meet shareholder investment } \\
\text { policy. }\end{array}$ & $\begin{array}{l}\text { Assumption } \\
\text { 1. Market and volume : Probable performing volume at } \\
90 \% . \\
\text { 2. Depreciation : Straight line method. } \\
\text { 3. Cash Flow Analysis } \\
\text { 4. IRR } \\
\text { 5. NPV } \\
\text { 6. Payback Period }\end{array}$ \\
\hline $\begin{array}{l}\text { 3. To recommend competitive } \\
\text { alternative. }\end{array}$ & VA/VE for building and equipment \\
\hline
\end{tabular}


etc. Studied by Wad and in $\frac{5}{5}$ suggested that the expansion of automotive sales and employment should be aligned with international competitiveness.

Finally, is to recommend competitive alternative of painting technology (Challenger technology). On this step, feasibility study alone is not sufficient to justify the best alternative to be selected. Further analysis using Value Analysis and Value Engineering was implemented to further justify the selection. In short, Table 1 summarizes the objectives and procedures to achieve these research objectives.

\subsection{Data Collection Method}

The data collection method in this study is done based on the qualitative and quantitative consideration. The qualitative data is obtained from two different ways. The first way is by benchmarking several automotive manufacturers in the world. The second way is by conducting direct interviews with the employers, company policy makers and from observations conducted in the selected departments in the related companies. Meanwhile the quantitative data is derived from the specific equation, quotations calculation underlined in the handbook ${ }^{6}$.

\subsection{Assumptions}

Besides the computation of the feasibility study, which is, based on most probable performing volume, the assumptions of others contribution cost are derived from previous year/quarter of financial statement. For the assumptions to be used, project manager must agree with the costing details and usually based on existing accounting data. The common assumptions that are used in this research are as follows:

i. Volume of the market is based on input from customers.

ii. Investment is based on approximate quotation from suppliers. iii. Selling price is a fixed price given by the users with $1 \%$ annual reduction.

iv. Cost of administration and operation are based on current cost of paint shop.

v. Depreciation is based on straight-line method.

\section{Results and Discussion}

Paint shop is relatively not as stable as other stages in automotive operations ${ }^{\underline{7}}$. In the batch production operation, flexible manufacturing system approach contributes to the increase of the quality ${ }^{\circ}$.

\subsection{Level of Technology Identification}

The painting application is a hazardous and taxing job. Critical criteria shall be considered among others are safety, quality, cost, delivery, environment and morale. Workers can be exposed to unsafe Volatile Organic Compound (VOCs), isocyanides and carcinogens. Widespread is ocyanate exposure can even occur when the spray painters are wearing protective gloves? Knowing the above condition, safety and morale of workforce who are working in the paint shop are a concern to the employer and union association. Once the criteria are satisfied to the minimum requirements as prescribed by the government regulations, then deeper assessment will be carried out.

Quality is often measured by appearance. Paint thickness varies due to applying material inconsistently, overspray and equipment default. Over spray will cost additional 15\% consumables material and need to be reworked. The most common reason for using robot is to reduce labor requirement, reduce cost via material reduction \& space requirement and improve repeatability of the process. Table 2 explains the summary of challenger technology versus current technology. In advance automotive assembly plants, the paint shop is aided with high tech- 
Table 2. Comparison between robot painting and manual painting

\begin{tabular}{|c|c|c|c|c|}
\hline \multirow{2}{*}{ Group Criteria Summary } & \multicolumn{2}{|c|}{ Robot Painting } & \multicolumn{2}{|c|}{ Manual Painting } \\
\hline & Merit & De Merit & Merit & De Merit \\
\hline $\begin{array}{l}\text { 1.Safety of the operators. } \\
\text { - Hazardous Chemicals } \\
\text { - Dangerous Environment } \\
\text { - Health hazard }\end{array}$ & $\begin{array}{l}\text { Reduce exposure to } \\
\text { hazardous chemicals }\end{array}$ & $\begin{array}{c}\text { Robots are } \\
\text { moving hazard }\end{array}$ & - & $\begin{array}{l}\text { Workers are exposed } \\
\text { to various hazardous } \\
\text { chemicals and moving } \\
\text { equipment. }\end{array}$ \\
\hline $\begin{array}{l}\text { 2. Quality. } \\
\text { - Defect Per Unit (DPU) } \\
\text { - Painting thickness } \\
\text { - } \text { Configuration for high mix } \\
\quad \text { production }\end{array}$ & $\begin{array}{l}\text { Consistency in } \\
\text { quality }\end{array}$ & - & - & $\begin{array}{l}\text { Not consistent due to } \\
\text { human factor }\end{array}$ \\
\hline $\begin{array}{l}\text { 3.Cost } \\
\text { - Investment Cost } \\
\text { - Paint material cost } \\
\text { - Space saving. }\end{array}$ & $\begin{array}{l}\text { Less paint material } \\
\text { usage due to higher } \\
\text { transfer efficiency }\end{array}$ & $\begin{array}{c}\text { High } \\
\text { Investment } \\
\text { Cost for robots } \\
\text { line }\end{array}$ & $\begin{array}{l}\text { Low } \\
\text { Investment } \\
\text { Cost }\end{array}$ & $\begin{array}{l}\text { Higher paint material } \\
\text { usage due to lower } \\
\text { transfer efficiency }\end{array}$ \\
\hline $\begin{array}{l}\text { 4.Delivery } \\
\text { - Capacity } \\
\text { - Tact-Time } \\
\text { - Complex spray path }\end{array}$ & $\begin{array}{l}\text { Able to meet the pre- } \\
\text { designed production } \\
\text { capacity at the } \\
\text { designated tact time } \\
\text { with high quality } \\
\text { finish }\end{array}$ & - & - & $\begin{array}{l}\text { Depending on the } \\
\text { availability of the painter }\end{array}$ \\
\hline $\begin{array}{l}\text { 5. Environment. } \\
\text { - Environment friendly due } \\
\text { to less VOC }\end{array}$ & $\begin{array}{l}\text { With painting robot, } \\
\text { air flow is reduced }\end{array}$ & - & - & $\begin{array}{c}\text { Higher air flow is needed } \\
\text { to provide safe work } \\
\text { space }\end{array}$ \\
\hline $\begin{array}{l}\text { 6.Morale } \\
\text { - Increase in technical level } \\
\text { and transfer of know-how }\end{array}$ & $\begin{array}{l}\text { Workers are placed in } \\
\text { supervisory roles to } \\
\text { maintain and operate } \\
\text { the robotic system }\end{array}$ & - & - & $\begin{array}{l}\text { Repetitive nature of the } \\
\text { painting task can also } \\
\text { cause fatigue, stress, and } \\
\text { injury }\end{array}$ \\
\hline
\end{tabular}


Table 3. Decision matrix on current and challenger paint technology

\begin{tabular}{|c|c|c|c|}
\hline No & Items & Current Technology & Challenger Technology \\
\hline a & Spray paint booths & 2 & 3 \\
b & Pressurize air & 1 & 3 \\
c & Transfer process & 2 & 3 \\
d & Painting process & 1 & 3 \\
e & Pre-treatment & 2 & 3 \\
\hline & Total & $\mathbf{8}$ & $\mathbf{1 5}$ \\
\hline
\end{tabular}

nology robots to increase product quality, flexible process and safety of workforce ${ }^{10}$.

Table 3 shows the summary of identification process of painting technology based on SGA with the industry experts. The comparison is made based on several parameters i.e. spray paint booths, pressurize air, transfer \& painting process and pre-treatment process. From the decision matrix, there are various considerable differences between the current technology and the most recent paint shop technology. The scores were based on the consensus among the member of SGA. Score 5 is an indication of excellent performance whereas score 1 indicates poor performance.

Tables 2 and 3 shows that team members prefer the proposed challenger technology.

\subsection{Feasibility Studies Results}

The feasibility study started with the evaluation and volume projection of the market demand. It is then followed by discussion of investment requirement either by company or market. This should include policy of depreciation, financial ratio and cost of fund. The result is then presented in the form of cash flow analysis. If the result meets the financial ratio guidelines set by company, then it leads to decision-making. If it does not meet the stipulated guidelines, the value engineering aspect will be carried out to find the best formulation to the result. The volume achievement of the previous model of product or similar product will also be analyzed to ensure the realistic volume projection.

Based on the most probable sales volume, gross profit, finance cost, and investments, the computation of the feasibility study can be performed. Table 4 shows the overall results of five years data and information. Net Present Value (NPV) represents the key point whether this project is feasible or not. The most important decision, of course, is whether or not to proceed with the project investment. The organisation must decide carefully about its financial objectives about whether to make a profit or to just break even, or whether it can afford to lose some money.

The result shown above which is derived from the calculation of the investment of RM 228,695,160 with the probable volume achievement of $90 \%$, is not financially feasible as the NPV is negative, the payback period is more than five (5) years and the rate of return is lower than the WACC of 12 per cent. Another indicator, the average break-even volume is calculated at 13,482 units per year. Even though the break-even point is achievable, the sensitivity analysis shown above does not support the 
Table 4. Net cash flow analysis for project

\begin{tabular}{|c|c|c|c|c|c|c|c|}
\hline Items & $\begin{array}{c}\text { FY 2015/16 } \\
\text { (RM) }\end{array}$ & $\begin{array}{c}\text { FY 2016/17 } \\
(\mathrm{RM})\end{array}$ & $\begin{array}{c}\text { FY } 2017 / 18 \\
(\mathrm{RM})\end{array}$ & $\begin{array}{c}\text { FY 2018/19 } \\
(\mathrm{RM})\end{array}$ & $\begin{array}{c}\text { FY 2019/20 } \\
(\mathrm{RM})\end{array}$ & $\begin{array}{c}\text { FY 2020/21 } \\
\text { (RM) }\end{array}$ & $\begin{array}{c}\text { FY } 2021 / 22 \\
(\mathrm{RM})\end{array}$ \\
\hline Sales & & $70,150,000$ & $93,119,400$ & $120,279,320$ & $144,442,700$ & $166,550,400$ & $201,637,500$ \\
\hline $\begin{array}{l}\text { Cost of } \\
\text { sales }\end{array}$ & & $(35,776,500)$ & $(47,863,372)$ & $(62,304,688)$ & $(75,399,089)$ & $(87,605,510)$ & $(106,867,875)$ \\
\hline Gross profit & & $34,373,500$ & $45,256,028$ & $57,974,632$ & $69,043,611$ & $78,944,890$ & $94,769,625$ \\
\hline $\begin{array}{l}\text { Net present } \\
\text { value } \\
(\mathrm{NPV})\end{array}$ & \multicolumn{4}{|c|}{$\mathrm{RM}(1,170,719)$} & \multicolumn{2}{|c|}{ Initial investment } & $228,095,160$ \\
\hline $\begin{array}{c}\text { Payback } \\
\text { period }\end{array}$ & \multicolumn{7}{|c|}{5.13 years } \\
\hline IRR & \multicolumn{7}{|c|}{$11.9 \%$} \\
\hline
\end{tabular}

results. Hence, the project management needs to carry out value engineering or cost saving in order to minimize the overall investment.

The biggest investment of this industry is in the equipment and building. It is therefore worthy to overcome negative value of NPV by conducting value engineering in terms of both equipment and building. Hence, the competitive alternatives measures are recommended to improve their financial result in the cash flow analysis.

\subsection{Value Engineering for Equipment}

This type of value engineering involves three options, namely reposition of paint receiving tanks to nearer to paint booths, changing method of dipping and spray and localization of the imported components and fabricated items.
The reposition of receiving tanks enables the reduction of the length of ongoing and return pipes. Apparently, it reduces total effective length by $20 \%$. Meanwhile, the changing method of dipping and spray has efficiently reduced the total length of tank by $20 \%$ as well, and the localization of the imported equipment as reduced logistic and fabrication costs.

Figure 1 shows that the equipment cost has reduced from RM 130 Mil to RM108 Mil. In VA/VE 1, the fabrication of booths, tanks and conveyors will be carried out locally while only specific pump, robotics lines, spray and electrical systems are imported from Japan and Germany and tremendously reduced the cost of manufacturing and logistic by RM20 Mil through localization of common equipment. 


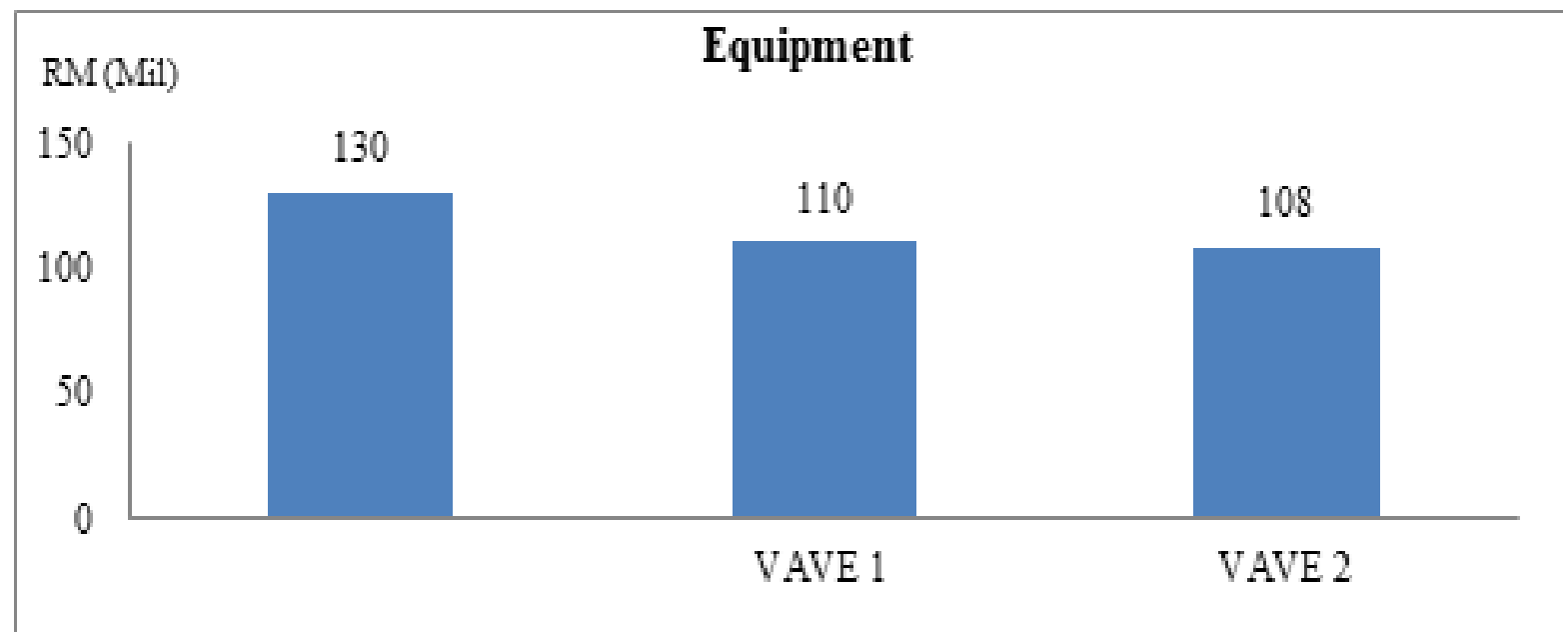

Figure 1. VA/VE for equipment.

Meanwhile, in VA/VE 2, the main activities involved the reposition of receiving tanks, methods of dipping and maintaining sewerage system. This has resulted in the cost reduction up to RM 12 Mil.

\subsection{Value Engineering for Building}

The second step of value engineering is on the factory floor cost which involves the relay-out floor footing foundation requirement according to machineries specification. Other working areas and utilities room can be set at lower tonnage requirement. Figure 2 illustrates the cost reduction activities. Safety factor is considered for equipment installation.

\subsubsection{VAVE No. 1}

This first way of value engineering involves activities such as the change of pilling work from hydraulic injection to

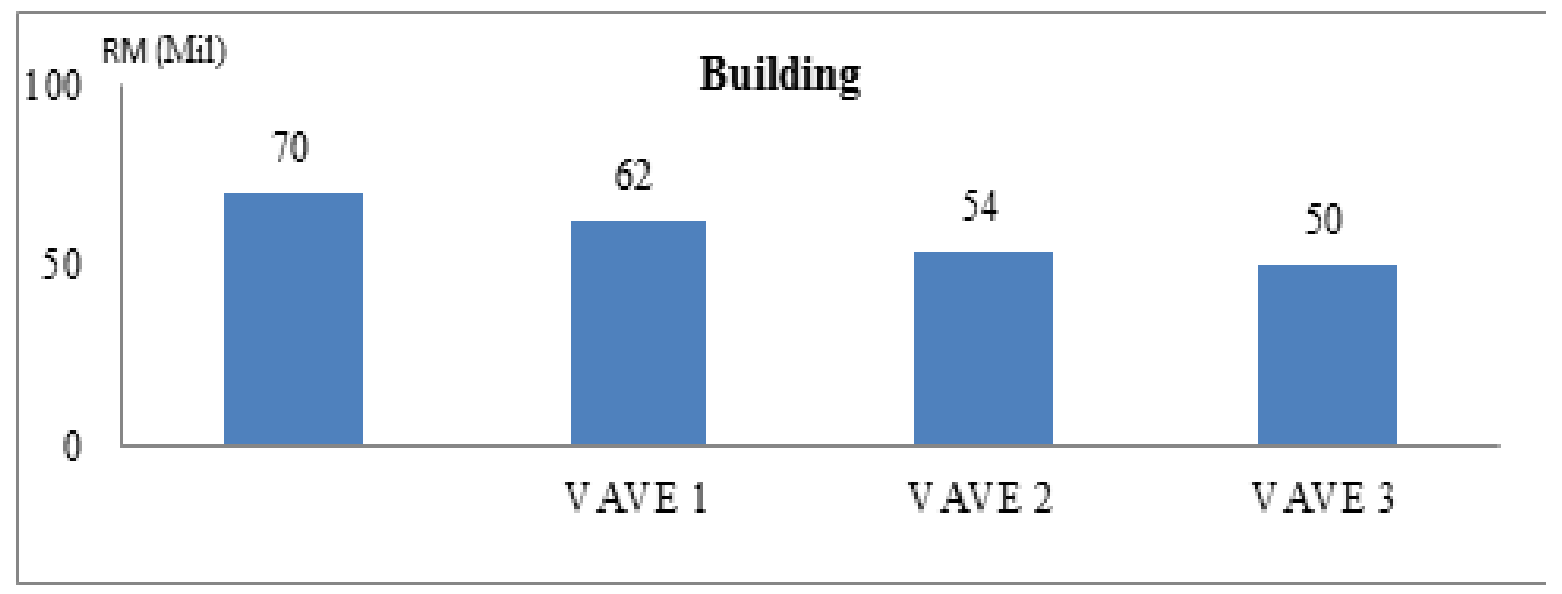

Figure 2. VA/VE for building. 
hammer type, change of concrete slab that use reinforcement bar to steel fiber reinforcement bar and reduction of factory size by eliminating space for non-direct production.

In changing the method of piling work from hydraulic injection to hammer type, the hammer pile can drive a minimum of 20 points of 42 meters pile as compared to 7 points for hydraulic injection. In addition to low cost of hammer pile mobilization, it also reduces the total cost of piling work. From the total of 2300 piling points, only 468 points will be driven by hydraulic injection pile. This has reduced the cost by $20 \%$.

For the concrete slab changes from reinforced bar to steel fiber reinforcement, since it does not require normal steel bar and interlink concrete beam, hence it reduces the concreting time and materials. Meanwhile, the factory size reduction is done by-eliminating space for non-direct production. For instance, the non-direct production space involves the management and production office areas, utilities stores, inventory for indirect material and for klift passage way. The most efficient space for manufacturing floor is $60 \% \underline{11}$.

\subsubsection{VAVE No. 2}

The second way for value engineering for building is restudying and specifying actual loading requirement of specific machines. It involves the following activities:

a. Reduce structure to support mezzanine floor. During machines installation, large machines can be skid mounted on temporary beams and 1-inch-thick plate to spread out the loads. Correspondingly, a specified travelling speed of the truck loaded with equipment should be controlled to avoid dynamic deflection of the supporting structure $\underline{\underline{12}}$ b. Reduce structure to support mezzanine floor. Change structural I beam to truss structure.

\subsubsection{VAVE No. 3}

The third way of VA/VE on building is derived as:

a. Reroute primary and secondary utilities for $M \& E$ services. Change 2604 meters length of copper cable to Aluminum material. Thus, reduce the purchase cost of cable and ease of installation.

b. Change the proposed roof material from lysaght to cycle wool composite insulated material. The insulated material compose in three layers will reduce the complexity of roof installation and materials price. This reduces the layout of material and installation time.

Based on the VAVE proposals, the investment for the project has therefore been revised as shown in the Table 5.

The localization of components and fabricated items can reduce the cost by RM $22 \mathrm{Mil}$ and redesign building work i.e. type of piling, reduction of structural steels, change of electrical specification, specification of floor loading requirement, change of concrete material and roofing material had contributed to reduction of further RM 20 Mil. To sum up, the activities of revisiting the initial investment via VA/VE application has resulted in reduction of RM $43 \mathrm{Mil}$ or $19 \%$. Using the revised investment, the cash flow analysis has been re-conducted and the result is tabulated in Table 6.

The economic analysis based on NPV, IRR and Payback Period has been performed to gauge the feasibility of the project based on the revised investment aided by the VA/VE. Table 6 shows at the most probable volume condition, all three economic measurement terms are in line with the financial guideline. Even at the worst volume condition, the payback period is still within the model used and the internal rate of return meets the financial 
Table 5. Revised investment based on VA/VE proposals

\begin{tabular}{|c|c|c|c|}
\hline No & Items & Investment (RM) & Revision (RM) \\
\hline 1 & 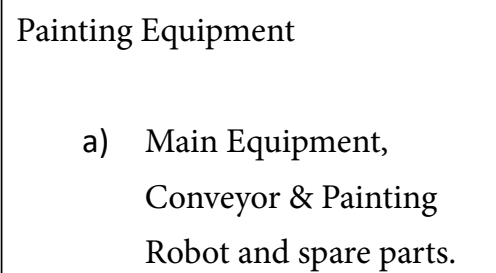 & $132,000,000.00$ & $110,000,500.00$ \\
\hline 2 & Tools, Jigs \& IT related & $4,000,000.00$ & $4,000,000.00$ \\
\hline 3 & 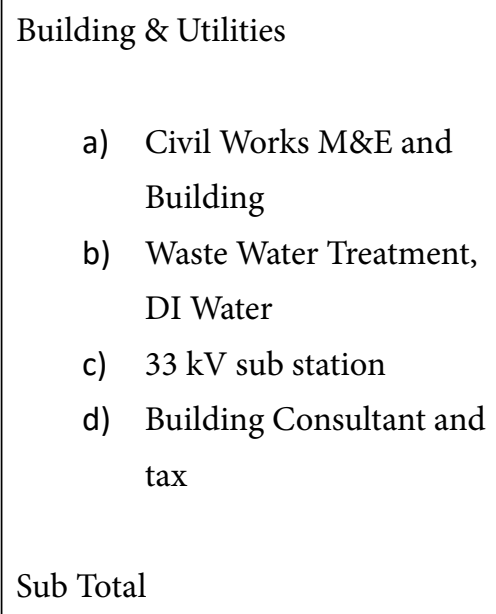 & $\begin{array}{l}70,000,000.00 \\
5,000,000.00 \\
8,000,000.00 \\
3,695,160.00 \\
86,695,160.00\end{array}$ & $\begin{array}{l}50,000,000.00 \\
4,950,000.00 \\
8,000,000.00 \\
2,332,000.00 \\
65,282,000.00\end{array}$ \\
\hline 4 & $\begin{array}{l}\text { a) Development Cost and } \\
\text { trial } \\
\text { b) Inspection equipment } \\
\text { Sub Total }\end{array}$ & $\begin{array}{l}3,000,000.00 \\
2,000,000.00 \\
6,000,000.00\end{array}$ & $\begin{array}{l}3,000,000.00 \\
2,000,000.00 \\
6,000,000.00\end{array}$ \\
\hline $\begin{array}{c}\text { Grand Total } \\
\quad(\mathrm{RM})\end{array}$ & & $228,695,160.00$ & $185,282,500$ \\
\hline
\end{tabular}


Table 6. Revised feasibility study based on volume scenario (RM '000)

\begin{tabular}{|c|c|c|c|c|c|c|c|}
\hline ITEM & $\begin{array}{c}\text { FY 2015/16 } \\
\text { (RM) }\end{array}$ & $\begin{array}{c}\text { FY } 2016 / 17 \\
(\mathrm{RM})\end{array}$ & $\begin{array}{c}\text { FY } 2017 / 18 \\
(\mathrm{RM})\end{array}$ & $\begin{array}{c}\text { FY 2018/19 } \\
(\mathrm{RM})\end{array}$ & $\begin{array}{c}\text { FY } 2019 / 20 \\
(\mathrm{RM})\end{array}$ & $\begin{array}{c}\text { FY 2020/21 } \\
(\mathrm{RM})\end{array}$ & $\begin{array}{c}\text { FY } 2021 / 22 \\
(\mathrm{RM})\end{array}$ \\
\hline Sales & & 63,135 & 84,502 & 108,741 & 130,923 & 151,070 & 182,311 \\
\hline Cost of sales & & $(32,198)$ & $(43,434)$ & $(56,328)$ & $(68,342)$ & $(79,463)$ & $(96,625)$ \\
\hline Gross profit & & 30,936 & 41,068 & 52,413 & 62,581 & 71,607 & 85,686 \\
\hline $\begin{array}{l}\text { Net present } \\
\text { value (NPV) }\end{array}$ & \multicolumn{7}{|c|}{ RM 19,609 } \\
\hline $\begin{array}{c}\text { Payback } \\
\text { Period }\end{array}$ & \multicolumn{7}{|c|}{4.83 years } \\
\hline IRR & \multicolumn{7}{|c|}{$14.6 \%$} \\
\hline
\end{tabular}

Table 7. Revised economic evaluation

\begin{tabular}{|c|c|c|c|c|c|c|}
\hline \multirow{2}{*}{ No } & \multirow{2}{*}{$\begin{array}{c}\text { Economic } \\
\text { Measurement }\end{array}$} & \multicolumn{4}{|c|}{ Volume Factor } & \multirow[t]{2}{*}{ Remarks } \\
\hline & & $\begin{array}{c}90 \% \\
\text { Guideline }\end{array}$ & $\begin{array}{l}100 \% \\
\text { Best }\end{array}$ & $\begin{array}{c}90 \% \\
\text { Most } \\
\text { probable } \\
\end{array}$ & $\begin{array}{c}85 \% \\
\text { Worst }\end{array}$ & \\
\hline 1 & $\begin{array}{l}\text { Net Present } \\
\text { Value }(\mathrm{RM})\end{array}$ & + ve & $40,553,872$ & $19,609,384$ & $8,631,498$ & $\begin{array}{l}\text { Positive NPV at the } \\
\text { most probable volume }\end{array}$ \\
\hline 2 & $\begin{array}{c}\text { Payback } \\
\text { Period (years) }\end{array}$ & $<5 \%$ & 4.58 & 4.83 & 4.98 & $\begin{array}{l}\text { Initial investments of } \\
\text { RM 185K could be } \\
\text { recovered within } 5 \text { years }\end{array}$ \\
\hline 3 & $\begin{array}{l}\text { Internal Rate } \\
\text { of Return (\%) }\end{array}$ & $>12 \%$ & $17.3 \%$ & $14.6 \%$ & $13.2 \%$ & $\begin{array}{l}\text { More than } 12 \% \text { at the } \\
\text { most probable volume }\end{array}$ \\
\hline
\end{tabular}


guideline. It can be seen that the NPV now is in a positive value up to RM 20 Mil. Payback period can be achieved in 4.83 years with IRR $14.6 \%$. Overall, evaluation of the capital investment of RM 185,282,500 for the agreed level of technology is with much improved safety and environment control, and is within the group financial guidelines. The result is shown in Table 7.

The Table 7 showed the most probable volume condition; all three economic measurement terms are in line with company financial guideline. Even at the worst volume condition, the payback period is still within the model used and internal rate of return met the financial guidelines. Overall, the evaluation of the capital investment of RM 185,282,500 for the agreed level of technology is with much improved safety and environment control, and is within the group financial guidelines.

\section{Conclusion}

The financial sensitivity analysis is an evaluation tool to analyze the financial potential of a proposed project. It is based on extensive financial investigation and research to support the process of decision-making. Thus, experimentation on the detailed simulations on the multi variable input such as sales of the car, manufacturing cost, time to deliver has been the way to guide the company and shareholder to make sound decision making. The two criteria to judge the financial feasibility are cost required and value to be attained. A well-designed sensitivity analysis study should provide accounting statements, cash flow analysis and financial data. In this work, a combination of feasibility study where the challenger was assessed through financial analysis such as Net Present Value (NPV), Internal Rate of Return (IRR), and Pay-Back Period (PBP) and Value Analysis and Value Engineering (VA/VE) were used to justify the selection of technology of painting. The results show that the challenger was preferable based on team assessor due to its technical superior over the current technology in terms of quality and safety. However, when it tested for feasibility study, the results were not encouraging. Then VA/VE method was used to investigate whether the challenger can fit financially to the requirement set at the beginning by the owner of the project. The final results approved that the challenger was selected. It proves that SA is the financial tool to support management decision on capital investment and the secondary tools VA/VE to optimize the investment.

\section{Acknowledgement}

The authors gratefully acknowledge Faculty of Manufacturing Engineering for the technical supports of this project.

\section{References}

1. Malaysian Automotive Outlook. Malaysian Automotive Association (MAA), Summary of Sales \& Production Data. Malaysia; 2014 Oct. p. 1-10.

2. Maag K, Lenhard W, Loffless $H$. New UV curving systems for automotive applications. Progress in Organic Coatings. 2000; 40(1-4):93-7. Crossref. https://doi.org/10.1016/ S0300-9440(00)00144-2

3. Howard M, Miemczyk J. Purchasing and supply chain management: A sustainability perspective. Business \& Economics. 2014:1-420.

4. Borgonovo E, Peccati L. Sensitivity analysis in investment project evaluation. International Journal of Production Economics. 2004; 90(1):17-25. Crossref. https://doi. org/10.1016/S0925-5273(03)00213-5

5. Wad P, Govindaraju C. Automotive industry in Malaysia: An assessment of its development. International Journal of Automotive Technology and Management. 2006; 11(2):152-171.

6. Nagane SG. Simulation study of multilane selectivity bank in automotive industry. Master Thesis, University of Kentucky; 2002. 
7. Wang J, Li J, Arinez J, Biller S. Quality bottleneck transitions in flexible manufacturing systems. IEEE International Conference on Robotics and Automation. Anchorage, Alaska, USA; 2010. p. 2119-24.

8. Kochan A. BMW uses even more robots for both flexibility and quality. An International Journal of Industrial Robot. 2005; 32(4):318-20. https://doi.org/10.1108/01439910510600173

9. Bello D, Redlich CA, Stowe MH. Skin exposure to aliphatic polyisocyanates in the auto body repair and finishing industry: II. A quantitative assessment. Annals of Occupational Hygiene. 2008; 52(2):117-24. PMid:18209009
10. Jovanovic P. Application of sensitivity analysis in investment project evaluation uncertainty and risk. International Journal of Project Management. 1999; 17(4):217-22. Crossref.

https://doi.org/10.1016/S0263-7863(98)00035-0

11. Johari S. Plant Engineering of HAMM, space productivity improvement at new paint shop area. Pekan, Malaysia; 2015.

12. Pan TC, Li J. Dynamic FE method for transient response of vehicle structure coupling system. Asia-Pacific Vibration Conference '99 (A-PVC'99). 1999; 1:30-5. 